Article

\title{
Modelling Effects of Rainfall Patterns on Runoff Generation and Soil Erosion Processes on Slopes
}

\author{
Qihua Ran ${ }^{1}$, Feng Wang ${ }^{1}\left(\mathbb{D}\right.$ and Jihui Gao ${ }^{1,2,3, *}$ \\ 1 Institute of Hydrology and Water Resources, Zhejiang University, Hangzhou 310058, China; \\ ranqihua@zju.edu.cn (Q.R.); wfno1@163.com (F.W.) \\ 2 State Key Laboratory of Hydraulics and Mountain River Engineering, Sichuan University, \\ Chengdu 610065, China \\ 3 School of Water Resource \& Hydropower, Sichuan University, Chengdu 610065, China \\ * Correspondence: jgao@scu.edu.cn
}

Received: 19 September 2019; Accepted: 22 October 2019; Published: 25 October 2019

\begin{abstract}
Rainfall patterns and landform characteristics are controlling factors in runoff and soil erosion processes. At a hillslope scale, there is still a lack of understanding of how rainfall temporal patterns affect these processes, especially on slopes with a wide range of gradients and length scales. Using a physically-based distributed hydrological model (InHM), these processes under different rainfall temporal patterns were simulated to illustrate this issue. Five rainfall patterns (constant, increasing, decreasing, rising-falling and falling-rising) were applied to slopes, whose gradients range from $5^{\circ}$ to $40^{\circ}$ and projective slope lengths range from $25 \mathrm{~m}$ to $200 \mathrm{~m}$. The rising-falling rainfall generally had the largest total runoff and soil erosion amount; while the constant rainfall had the lowest ones when the projective slope length was less than $100 \mathrm{~m}$. The critical slope of total runoff was $15^{\circ}$, which was independent of rainfall pattern and slope length. However, the critical slope of soil erosion amount decreased from $35^{\circ}$ to $25^{\circ}$ with increasing projective slope length. The increasing rainfall had the highest peak discharge and erosion rate just at the end of the peak rainfall intensity. The peak value discharges and erosion rates of decreasing and rising-falling rainfalls were several minutes later than the peak rainfall intensity.
\end{abstract}

Keywords: rainfall patterns; rainfall-runoff; soil erosion; slope length; slope gradient; InHM

\section{Introduction}

Rainfall patterns and landform characteristics are controlling factors of the runoff and soil erosion processes in natural catchments [1,2]. Due to climatic change and climatic variability, rainfall events commonly show great temporal variation in intensity, especially in hilly areas [3,4] and the peak rainfall rates within an event may dozens of times higher than the mean event rate [1,5]. Although the temporal distribution of an individual rainfall event is diverse, some patterns of such distribution in a region can be derived based on historical data (e.g., [6,7]).

Previous studies have recognized that the rainfall patterns greatly affect the runoff generation and soil erosion processes (e.g., [8,9]). Parsons and Stone [10] adopted five rainfalls with different patterns but the same total kinetic energy to the soil surface. They found that the soil erosion amount under a constant-intensity storm are reduced by about $25 \%$ compared to varied-intensity storms, and that the eroded sediments are coarser under the constant-intensity pattern. An et al. [8] used the similar rainfall patterns and indicated that, although the total runoff was nearly not affected by the rainfall pattern, the varied intensity patterns yield 1-5 times more soil losses than even-intensity patterns and the rising pattern resulted in a consistently higher soil loss relative to the other four rainfall patterns. Conversely, Dunkerley [3] performed rainfall simulations of varying intensity profile in a dryland intergrove (runoff source area) and discovered that the late peak events showed runoff ratios that were 
more than double those of the early peak events and the constant rainfall yielded the lowest total runoff, the lowest peak runoff rate. The reason was inferred to be the reductions in soil infiltration capacity during late rainfall. Zhai et al. [11] applied a distributed hydrological model at the basin scale, and found that the rainfall patterns have significant impact on the rainfall threshold of flood warning, which the flood rainfall threshold of advanced rainfall is the highest.

However, in most studies on rainfall pattern at plot scale, spatially distributed results of infiltration and soil erosion processes were not carefully considered. The temporal variation of precipitation can lead to corresponding spatial and temporal variations of infiltration, overland flow generation, and further soil erosion. Only considering runoff and soil erosion data at plot outlet, like many previous study did, will miss some important information (e.g., distributed cumulative infiltration or erosion depth) within the study area for comprehensive interpreting the influence of rainfall pattern on runoff and soil erosion processes.

In recent years, many studies on slopes have reported that observed runoff coefficient in Hortonian runoff processes decreases with increasing slope length, and variance of runoff reduces as slope scale increases (e.g., [12,13]). A reason was that the runoff generated upslope can infiltrate in downslope areas, which was called the run-on infiltration [14] or the re-infiltration [15]. Although rainfall characteristics such as duration were one of the major factors affecting runoff generation at different slope scales (e.g., [16]), it is still unknown how slope length influences the effect of temporal rainfall pattern on rainfall-runoff and soil erosion processes.

Slope steepness was an important topographic factor of hillslope rainfall-runoff and soil erosion processes. At plot scale, contradictory results were derived regarding slope effects on infiltration (e.g., $[17,18])$ and soil erosion (e.g., $[19,20])$. Besides, some researchers observed that runoff volume and soil loss on slopes increases with increasing slope angle till a critical slope angle of $20^{\circ}-30^{\circ}$ (e.g., [21]), while others reported that soil erosion is not correlated with slope gradient in tilled fields (e.g., [22]). However, a majority of the studies focusing on slope steepness neglected the influence of rainfall temporal variation. There is a lack of systematically studies on the effect of slope gradient under different rainfall patterns.

Numerical modelling is an effective approach to reveal spatial and temporal impacts of rainfall patterns on infiltration, overland flow and soil erosion processes at slopes with wide ranges of steepness and length, which can broaden the limitation of the artificial rainfall experiment (e.g., a plot with a few meters long [8]). Further, strictly controlling factors such as initial condition and soil property, the effect of rainfall patterns can be specifically focused. As a mature hydraulic model, Integrated Hydrology Model (InHM) can quantitatively simulate surface (2D) and subsurface (3D) hydrologic responses to rainfall in a fully coupled approach [23,24]. Previously, InHM has been successfully applied in the simulations of hillslope hydrology and slope failure (e.g., [23,25]). As this physics-based hydrological model employs fundamental physics laws to describe natural processes [26], its output results have clear physical meanings and can be used to generalize our understanding of rainfall pattern effects on runoff and soil erosion processes.

The main purpose of this study is to investigate the impact of rainfall temporal patterns on infiltration, runoff generation and soil erosion on slopes with a range of slope lengths and gradients, using a physically based modelling approach. These modelling results are expected to improve the theoretical basis for hillslope runoff and soil erosion prediction, which will be further helpful in soil conservation planning and land management.

\section{Methodology}

\subsection{InHM Model}

The Integrated Hydrology Model (InHM) was originally developed by VanderKwaak [27], which exceeds the specifications of the hydrologic-response model proposed by Freeze and Harlan (1969) that the model based upon the numerical solution to an almost-complete set of coupled partial 
differential equations which describe water movement processes at surface and in unsaturated and saturated subsurface [26]. With the advantage of the model that it doesn't need a priori assumption of a dominant runoff-generation mechanism [28,29], InHM is capable of accurately simulating dynamic infiltration, runoff and sediment processes under temporal varying rainfall. Previous studies have shown that the calibrated model reproduced accurately measured runoff and soil erosion results on semiarid hillslopes during constant-intensity rainfall-simulation events $[28,30]$. The equations and a detailed description of InHM can be found in VanderKwaak [27], VanderKwaak and Loague [26] and Heppner et al. [30].

\subsection{Model Setup}

Runoff and soil erosion processes were simulated and analysed on slopes with four horizontal projective slope lengths $(25 \mathrm{~m}, 50 \mathrm{~m}, 100 \mathrm{~m}$ and $200 \mathrm{~m})$, which were all $40 \mathrm{~m}$ wide and $3 \mathrm{~m}$ deep. For each horizontal projective length, nine slope gradients from $5^{\circ}$ to $40^{\circ}$ in $5^{\circ}$ increments were considered, and identical rainfall amount revieved on slope surfaces was ensured for different slope gradients due to the constant horizontal projective length. In total, for each rainfall scenario the runoff and erosion processes were simulated for 36 slopes. The schematic representation of the $200 \mathrm{~m}$ slope used in the simulation was shown in Figure 1 as an example. To avoid the influence of the downstream outlet boundary, the overall projective slope length of the 3D finite element meshes were $220 \mathrm{~m}$. The vertical nodal spacing $(\mathrm{Dz})$ in the mesh varies from 0.01 to $0.1 \mathrm{~m}$; the horizontal nodal spacing (Dx, Dy) is $0.5 \mathrm{~m}$. The 3-m mesh depth was sufficient for short-time simulation of rainfall-runoff events and deep groundwater movement was not considered in this study. The boundary conditions contain impermeable boundaries (A-E-H-D, B-F-G-C, E-F-G-H), flux boundary (A-E-F-B) and permeable boundary (A-B-C-D, C-G-H-D). The total numbers of the nodes and the elements of the $200 \mathrm{~m}$ slope 3D meshes are 35,721 and 70,400, respectively.

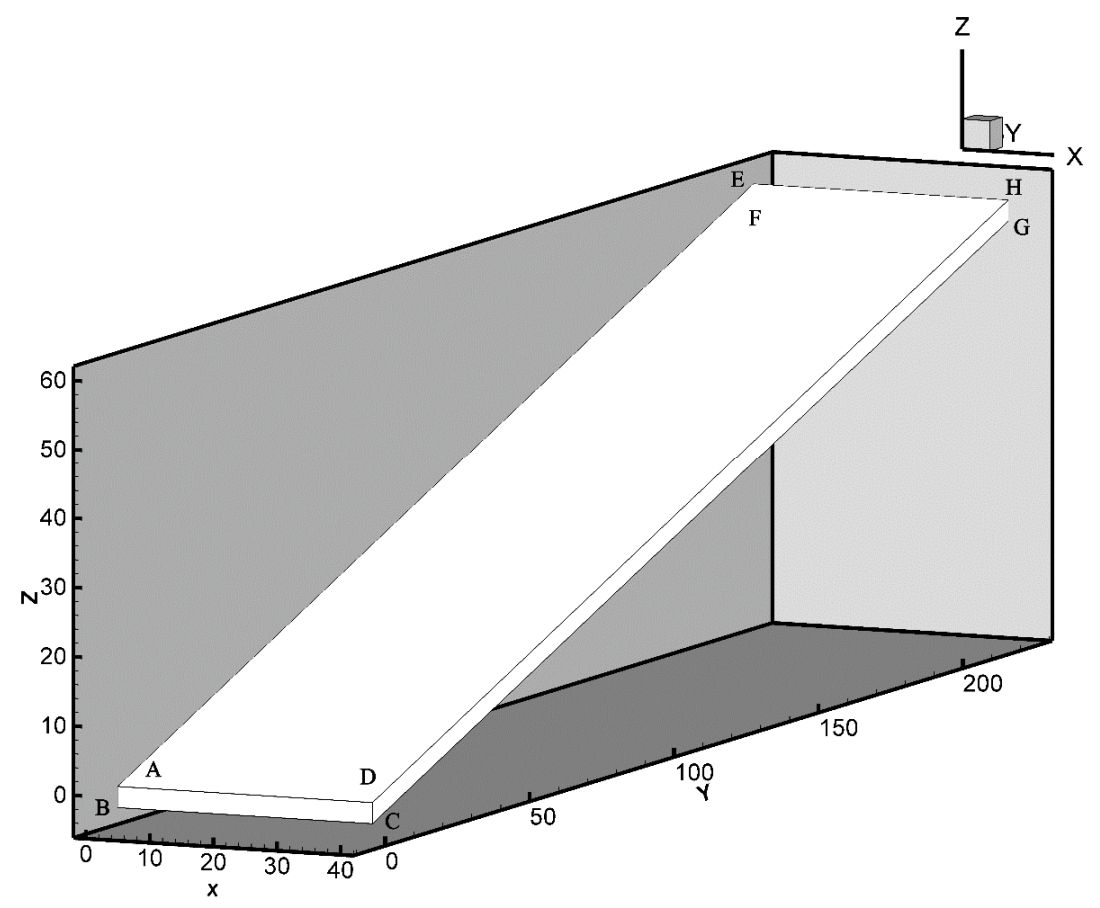

Figure 1. The schematic representation of the $200 \mathrm{~m}$ slope used the InHM modeling, and A-H represents each of the boundary nodes.

In this modelling study, the parameters of the plots (Table 1) were obtained from Ran et al. [28] who calibrated and validated the InHM parameters via the plot-scale experiments of Horton overland flow and surface erosion on the silty clay loam slopes within the Los Alamos National Laboratory [31]. 
The slope gradient of their experimental plot was $25.8^{\circ}$ and its vegetation coverage was $61 \%$, which was an ideal condition for hillslope runoff and soil erosion study. A 1-h $40 \mathrm{~mm} \mathrm{~h}^{-1}$ rainfall event is approximately equivalent to a 5-year return period event in that area.

Table 1. Parameters for the simulation.

\begin{tabular}{cc}
\hline Parameters & Value \\
\hline Porosity & 0.46 \\
Species average grain diameter & $2.0 \times 10^{-5} \mathrm{~m}$ \\
Manning coefficient & 0.275 \\
Initial water table & $-5 \mathrm{~m}$ \\
Mobile water depth (i.e., depression storage) & $5 \times 10^{-4} \mathrm{~m}$ \\
Height of microtopography & $0.01 \mathrm{~m}$ \\
& $\alpha: 1.0$ \\
Soil-water retention function (van Genuchten approach [32]) & $n: 1.23$ \\
& $\theta_{\mathrm{r}}: 0.088$ \\
Saturated hydraulic conductivity (Ks) & $10.8 \mathrm{~mm} \mathrm{~h}^{-1}$ \\
Rainsplash coefficient & 2.93 \\
\hline
\end{tabular}

\subsection{Rainfall Scenarios}

In this study, five temporal patterns of rainfall intensity were designed: constant rainfall intensity, increasing rainfall intensity, decreasing rainfall intensity, rising-falling rainfall intensity and falling-rising rainfall intensity (Figure 2).
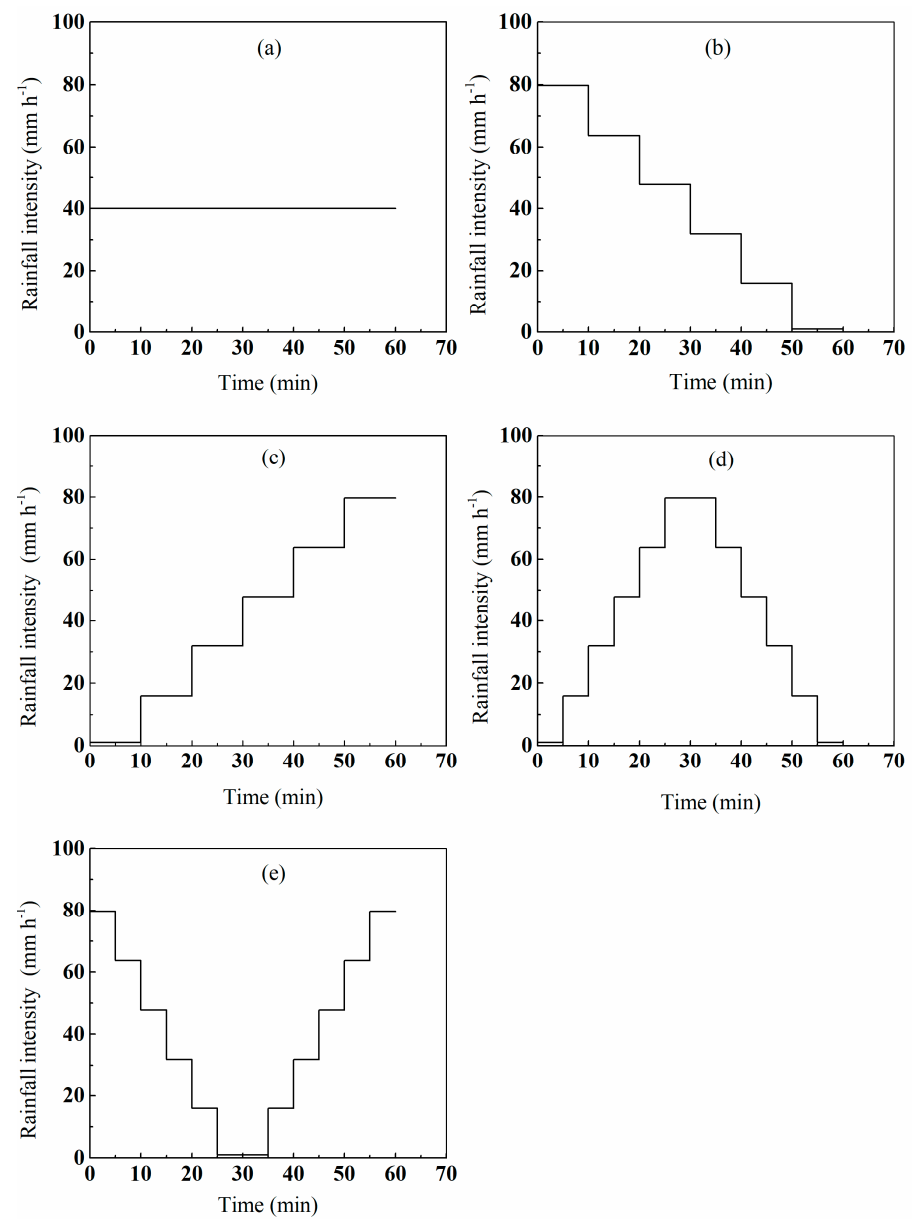

Figure 2. Five different rainfall patterns. (a) constant, (b) decreasing, (c) increasing, (d) rising-falling and (e) falling-rising. 
Similar rainfall scenarios were also adopted by other researchers foucusing on temporal patterns of rainfall (e.g., [3,33]). All the five rainfall patterns had a 1-h duration and $40 \mathrm{~mm}$ rainfall depth. Previously, many studies focusing on rainfall patterns adopted extremely high rainfall intensities in their rainfall simulations [1]. For instance, Flanagan et al. [34] used rainfall rates that peaked at $250 \mathrm{~mm} \mathrm{~h}^{-1}$ and Parsons and Stone [10] adopted rainfall rates in the range $46.4-170.8 \mathrm{~mm} \mathrm{~h}^{-1}$. The rainfall intensities of this study were within the range of $1-80 \mathrm{~mm} \mathrm{~h}^{-1}$, which reprensents a more general condition.

\section{Results}

\subsection{Hydrological Responses}

The modelling results of runoff in the rainfall scenarios at the different projective slope lengths were summarized in Table 2. Generally, the increasing and rising-falling rainfalls had the largest total runoff, and the constant and falling-rising rainfalls had the least total runoff. The constant rainfall had the lowest total runoff when the slope length was shorter than $100 \mathrm{~m}$. At a same slope gradient, the relative difference between the total runoff of different rainfall patterns was up to $111 \%$ (Table 2). The runoff coefficient at different projective slope lengths were shown in Figure 3. The runoff coefficient increased with increasing slope gradient until $15^{\circ}$ and then decreased to the lowest value at $40^{\circ}$ slope. The runoff coefficients of the rising-falling rainfalls were close to those of the increasing rainfalls at the $25 \mathrm{~m}$ slope, then they gradually became higher as slope length increased. As the projective slope length increased, the runoff coefficient of all the five rainfall patterns decreased, and that of the falling-rising rainfall decreased most greatly.

The peak discharge of the constant rainfall was the lowest (e.g., Figure 4). For increasing rainfall, the discharge rate kept increasing with time and reached the highest peak value among the five rainfall patterns at the end of the event. For the decreasing and rising-falling rainfalls, the peak discharges (Figure 4) were several minutes after the rainfall intensity decreased (Figure 2). The peak discharge of the falling-rising rainfall dropped a lot compared with other rainfalls as the projective slope length increased from $25 \mathrm{~m}$ to $200 \mathrm{~m}$.

Table 2. Simulated results of total runoff $\left(\mathrm{m}^{3}\right)$ at different projective slope lengths.

\begin{tabular}{cccccccccc}
\hline Projective Slope Length $(\mathbf{m})$ & Rainfall Pattern & $\mathbf{5}^{\circ}$ & $\mathbf{1 0}^{\circ}$ & $\mathbf{1 5}^{\circ}$ & $\mathbf{2 0}^{\circ}$ & $\mathbf{2 5}^{\circ}$ & $\mathbf{3 0}^{\circ}$ & $\mathbf{3 5}^{\circ}$ & $\mathbf{4 0}^{\circ}$ \\
\hline \multirow{3}{*}{25} & Constant & 13.3 & 14.1 & 14.3 & 14.3 & 14.0 & 13.5 & 12.7 & 11.8 \\
& Decreasing & 15.9 & 16.5 & 16.6 & 16.5 & 16.1 & 15.5 & 14.6 & 13.5 \\
& Increasing & 17.3 & 18.1 & 18.3 & 18.3 & 18.0 & 17.4 & 16.7 & 15.7 \\
& Rising-falling & 17.6 & 18.2 & 18.3 & 18.1 & 17.8 & 17.2 & 16.4 & 15.3 \\
& Falling-rising & 14.3 & 15.4 & 15.8 & 15.8 & 15.5 & 15.0 & 14.3 & 13.3 \\
\hline \multirow{3}{*}{50} & Constant & 21.7 & 23.4 & 23.7 & 23.4 & 22.5 & 21.1 & 19.2 & 16.9 \\
& Decreasing & 27.8 & 29.2 & 29.3 & 28.7 & 27.7 & 26.1 & 24.0 & 21.4 \\
& Increasing & 29.4 & 31.3 & 31.9 & 31.7 & 31.0 & 29.7 & 28.0 & 25.7 \\
& Rising-falling & 30.5 & 32.3 & 32.6 & 32.3 & 31.4 & 30.1 & 28.2 & 25.7 \\
& Falling-rising & 22.0 & 24.6 & 25.5 & 25.4 & 24.7 & 23.5 & 21.7 & 19.6 \\
\hline \multirow{3}{*}{100} & Constant & 32.8 & 36.9 & 37.9 & 37.2 & 35.3 & 32.3 & 28.3 & 23.5 \\
& Decreasing & 45.0 & 49.3 & 50.3 & 49.5 & 47.4 & 44.1 & 39.6 & 33.9 \\
& Increasing & 47.3 & 51.8 & 53.2 & 52.9 & 51.3 & 48.5 & 44.6 & 39.5 \\
& Rising-falling & 49.6 & 54.3 & 55.6 & 55.3 & 53.6 & 50.8 & 46.8 & 41.5 \\
& Falling-rising & 30.0 & 35.6 & 37.6 & 37.7 & 36.4 & 33.9 & 30.4 & 26.2 \\
\hline \multirow{3}{*}{200} & Constant & 43.4 & 51.5 & 53.9 & 52.9 & 49.2 & 43.3 & 35.7 & 27.4 \\
& Decreasing & 65.9 & 74.9 & 77.8 & 76.8 & 73.0 & 66.3 & 57.2 & 45.7 \\
& Increasing & 69.7 & 79.9 & 82.8 & 82.0 & 78.3 & 72.1 & 63.4 & 52.2 \\
& Rising-falling & 75.4 & 84.6 & 87.3 & 86.6 & 83.0 & 76.9 & 68.0 & 56.6 \\
& Falling-rising & 35.8 & 44.9 & 48.4 & 48.4 & 46.0 & 41.4 & 35.5 & 29.1 \\
\hline
\end{tabular}


Water 2019, 11, 2221

6 of 16

(a)

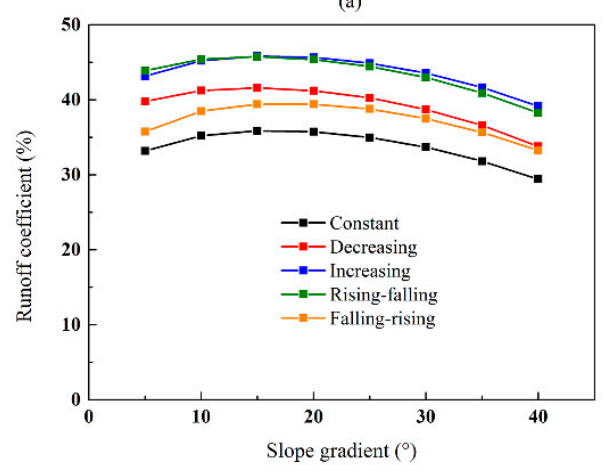

(c)

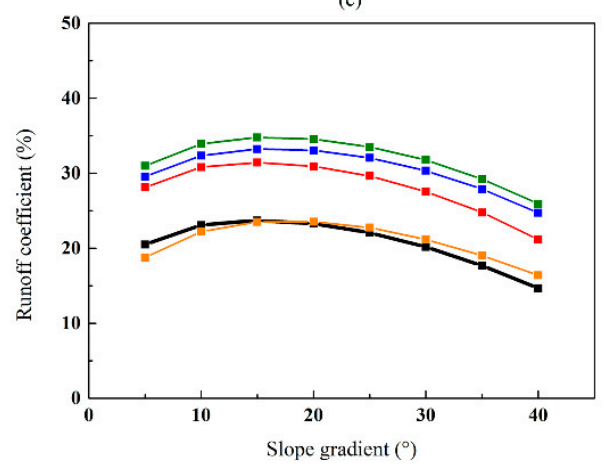

(b)

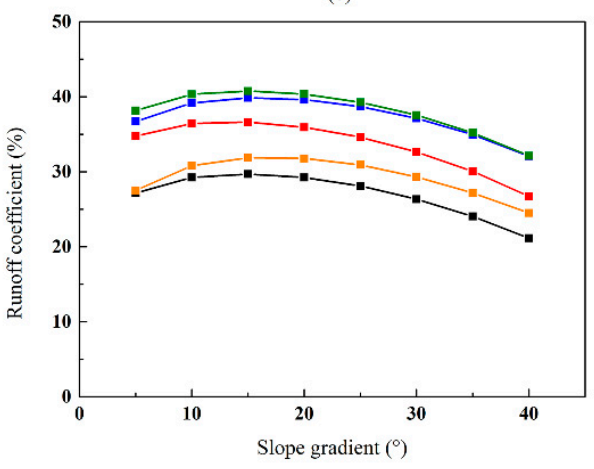

(d)

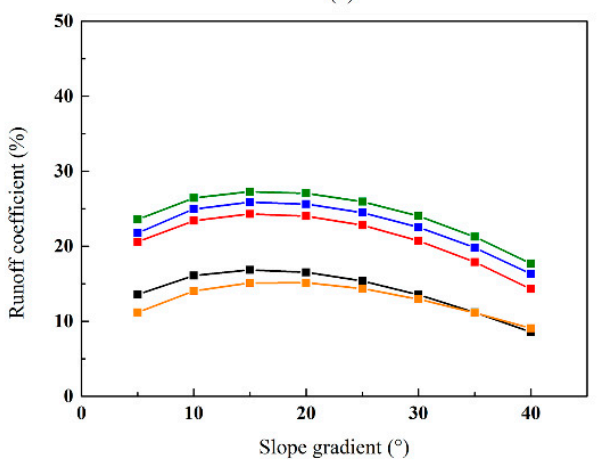

Figure 3. The runoff coefficient at different slopes with projective slope lengths of (a) $25 \mathrm{~m}$, (b) $50 \mathrm{~m}$, (c) $100 \mathrm{~m}$ and (d) $200 \mathrm{~m}$.

(a)

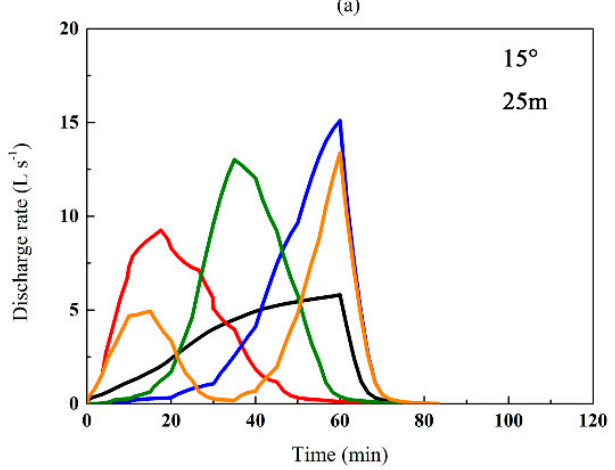

(c)

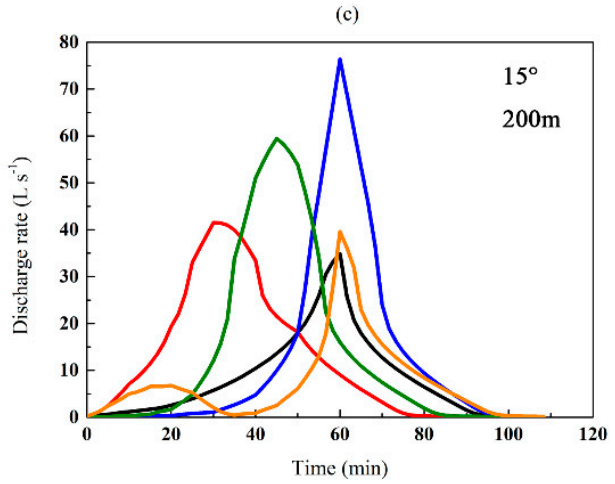

(b)

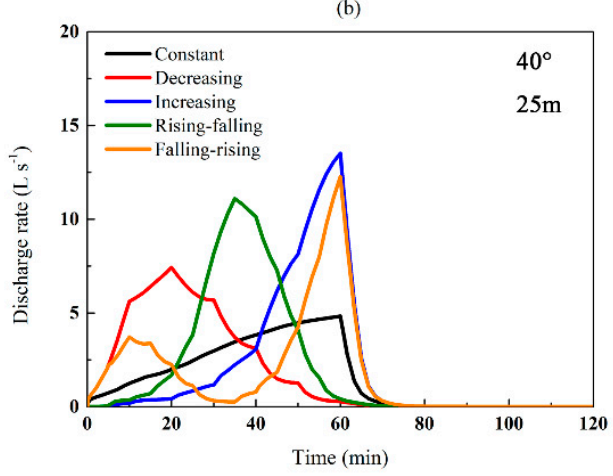

(d)

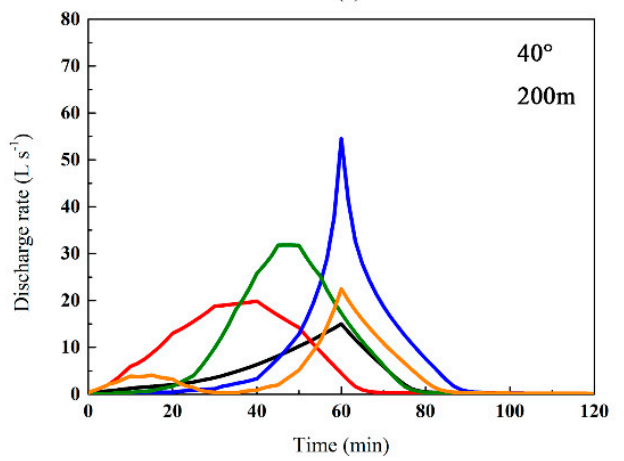

Figure 4. The hydrograph of five different rainfall patterns with $25 \mathrm{~m}$ and 200 projective slope lengths at $15^{\circ}$ slope $(\mathbf{a}, \mathbf{c})$ and $40^{\circ}$ slope $(\mathbf{b}, \mathbf{d})$, respectively. 


\subsection{Soil Erosion}

The soil erosion results of the rainfall scenarios at different projective slope lengths were summarized in Table 3. Similar to the hydrologic-response results, the increasing and rising-falling rainfalls had the largest total soil erosion, and the constant and falling-rising rainfalls had the least total soil erosion. This is due to the fact that rainfall-runoff was the controlling factor for soil erosion at the plot scale. Besides, at a same slope gradient, the relative difference between the soil erosion amounts of different rainfall patterns was up to 381\% (Table 3). In general, relative differences in soil erosion among the five rainfall patterns were higher than relative differences in runoff under the same condition. The soil erosion amount at the different projective slope lengths were shown in Figure 5. Different from the runoff coefficient, the slope gradients that had the peak values of soil erosion amount were around $25^{\circ}-40^{\circ}$, and this critical slope gradient decreased as projective slope length increased. Soil erosion amount of the rising-falling rainfalls became higher than that of the increasing rainfalls when slope length over $50 \mathrm{~m}$. When the slope lengths were 25-100 m, soil erosion amount of the constant rainfalls were the lowest among the five rainfall patterns; while it became higher than that of the falling-rising rainfall when the slope length was $200 \mathrm{~m}$. The sedigraphs were similar with the corresponding hydrographs. However, the erosion rate at the $40^{\circ}$ slope with $25 \mathrm{~m}$ slope length was much higher than that at the $15^{\circ}$ slope (Figure $6 \mathrm{a}, \mathrm{b}$ ), even the hydrographs at the two slopes only had small differences (Figure $4 a, b$ ). An example under rising-falling rainfall with $25 \mathrm{~m}$ slope length was shown in Figure 7.

Table 3. Simulated results of total soil erosion $(\mathrm{kg})$ at different projective slope lengths.

\begin{tabular}{|c|c|c|c|c|c|c|c|c|c|}
\hline Projective Slope Length (m) & $\begin{array}{l}\text { Rainfall } \\
\text { Pattern }\end{array}$ & $5^{\circ}$ & $10^{\circ}$ & $15^{\circ}$ & $20^{\circ}$ & $25^{\circ}$ & $30^{\circ}$ & $35^{\circ}$ & $40^{\circ}$ \\
\hline \multirow{4}{*}{25} & Constant & 66 & 201 & 385 & 610 & 867 & 1149 & 1426 & 1666 \\
\hline & Increasing & 179 & 599 & 1198 & 1961 & 2888 & 3715 & 3965 & 3888 \\
\hline & Rising-falling & 175 & 567 & 1114 & 1797 & 2607 & 3446 & 3717 & 3620 \\
\hline & Falling-rising & 102 & 352 & 722 & 1191 & 1757 & 2329 & 2592 & 2618 \\
\hline \multirow{4}{*}{50} & Decreasing & 411 & 1452 & 2935 & 4729 & 6704 & 7837 & 7534 & 6590 \\
\hline & Increasing & 586 & 2116 & 4442 & 7445 & 9636 & 10,154 & 9842 & 9102 \\
\hline & Rising-falling & 581 & 2127 & 4426 & 7338 & 10,017 & 10,480 & 9993 & 9123 \\
\hline & Falling-rising & 261 & 1058 & 2314 & 3931 & 5598 & 6258 & 6210 & 5762 \\
\hline 100 & Constant & 547 & 2199 & 4662 & 7566 & 10,401 & 10,845 & 9622 & 7629 \\
\hline \multirow{5}{*}{200} & Constant & 955 & 4250 & 9193 & 14,618 & 17,358 & 16,384 & 13,373 & 9548 \\
\hline & Decreasing & 2205 & 9037 & 19,436 & 28,850 & 30,831 & 28,977 & 24,982 & 19,345 \\
\hline & Increasing & 2895 & 13,002 & 27,699 & 32,262 & 33,449 & 31,753 & 28,030 & 22,777 \\
\hline & Rising-falling & 3179 & 13,562 & 29,359 & 34,865 & 36,063 & 34,389 & 30,605 & 25,198 \\
\hline & Falling-rising & 660 & 3370 & 7866 & 12,564 & 15,046 & 14,901 & 13,047 & 10,428 \\
\hline
\end{tabular}



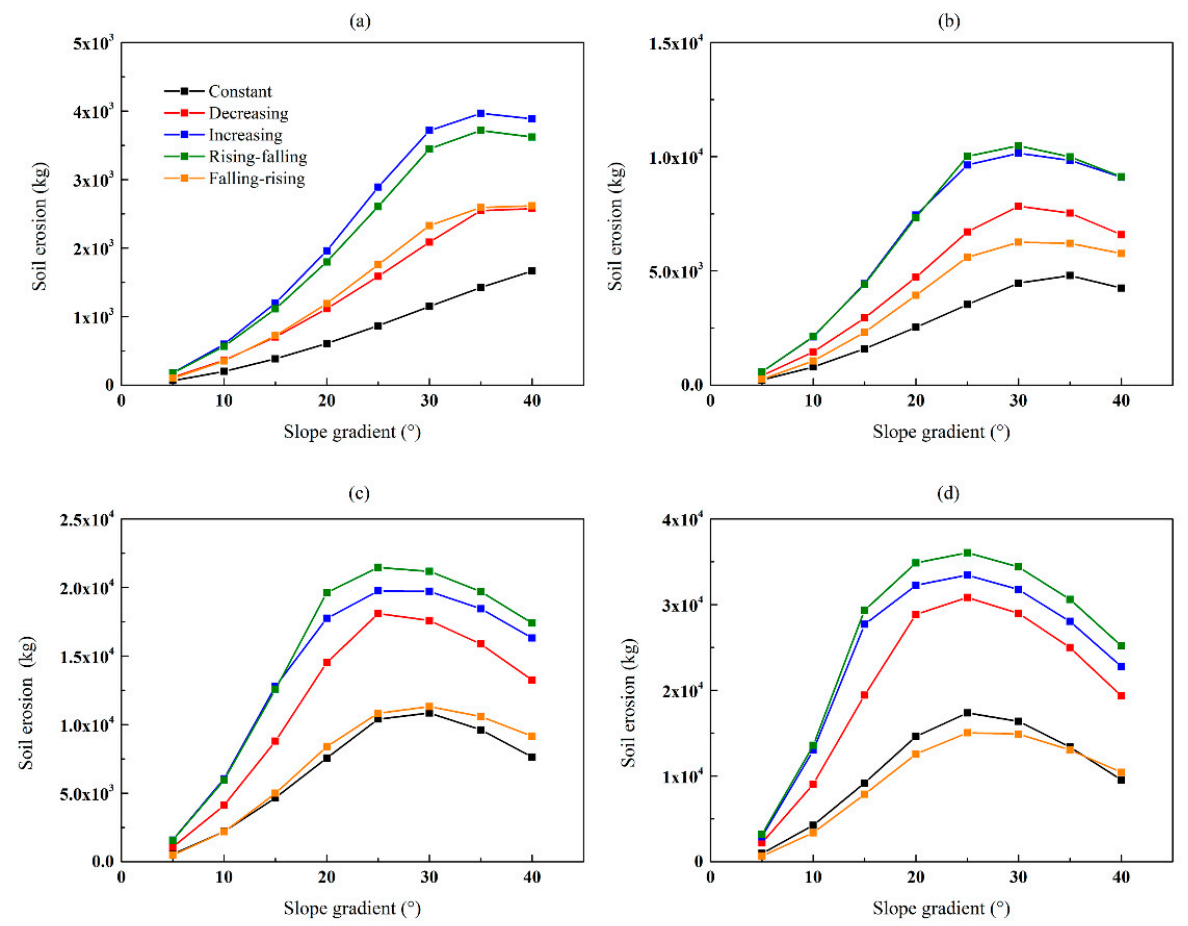

Figure 5. The soil erosion amount at different slopes with projective slope lengths of (a) $25 \mathrm{~m}$, (b) $50 \mathrm{~m}$, (c) $100 \mathrm{~m}$ and (d) $200 \mathrm{~m}$.
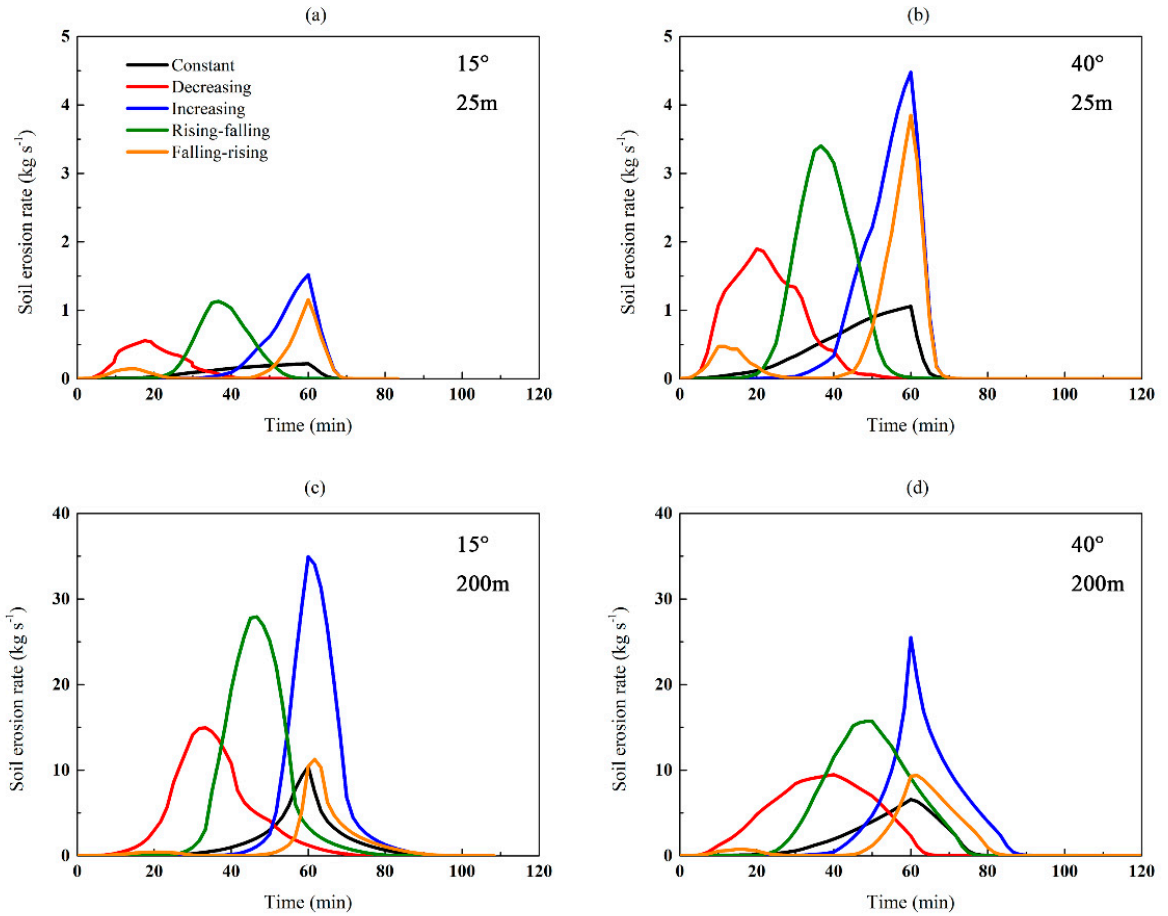

Figure 6. The sedigraphs of five different rainfall patterns with $25 \mathrm{~m}$ and 200 projective slope lengths at $15^{\circ}$ slope $(\mathbf{a}, \mathbf{c})$ and $40^{\circ}$ slope $(\mathbf{b}, \mathbf{d})$, respectively. 


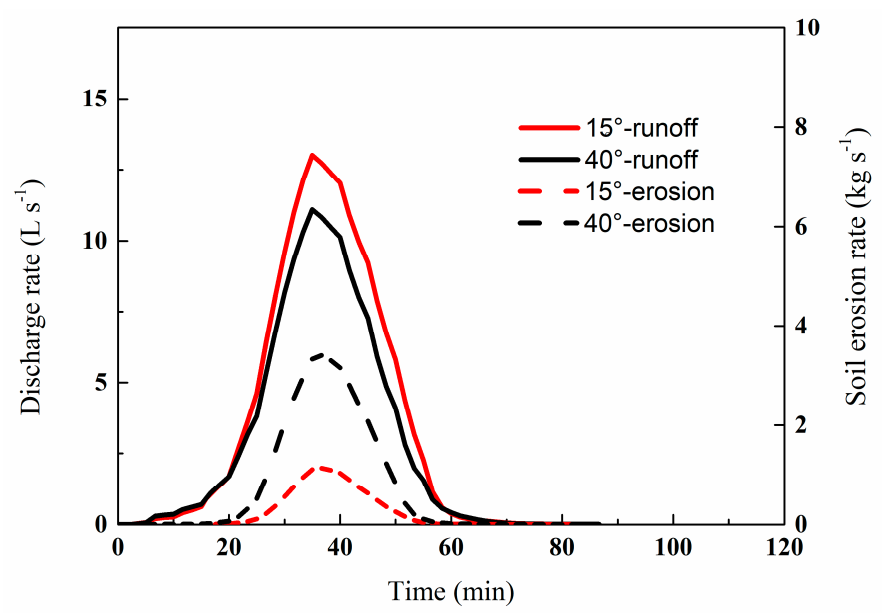

Figure 7. The comparison between the hydrographs and the sedigraphs under rising-falling rainfall at $25 \mathrm{~m}$ slope.

\section{Discussion}

\subsection{Effect of Rainfall Patterns on Total Runoff and Soil Erosion at Different Slope Lengths}

For constant rainfalls, their total runoff and soil erosion were lower than those of increasing rainfalls, decreasing rainfalls and rising-falling rainfalls. It was consistent with previous studies. Dunkerley [3] observed that the runoff ratios of varying intensity rainfalls were $85-570 \%$ larger than that of constant rainfall and Wang et al. [35] found that the constant rainfall produced the lowest sediment yield at around $61.8 \%$ of the average soil loss for the increasing rainfall. Comparing the cumulative infiltration of increasing rainfalls, decreasing rainfalls and rising-falling rainfall with that of constant rainfalls (Figure 8), their gaps almost reached the highest value when slope was around $12 \mathrm{~m}$, and then gradually stabilized as projective slope length increased. Thus, the differences in total runoff and soil erosion between these inconstant and constant rainfalls increased with increasing slope length. However, the total runoff and soil erosion amount of the constant rainfall become larger than those of falling-rising rainfall when the projective slope length was over $100 \mathrm{~m}$ (Figures 3 and 5). Previous experimental studies did not find this as their plots were much shorter than $100 \mathrm{~m}$. For instance, Wang et al. [35] adopted $2 \mathrm{~m}$-long flume and Parsons and Stone [10] used $2.45 \mathrm{~m}$-long flume in their rainfall exerpiments.

The cumulative infiltration of the constant rainfall along the slope axis was the highest, until the projective slope length was around $50 \mathrm{~m}$ as the cumulative infiltration of falling-rising rainfall became larger (Figure 8). When the slope was short, compared with the constant rainfall, there was not much water infiltrated downstream the slope during the low rainfall intensity period (i.e., rainfall intensity $=1 \mathrm{~mm} \mathrm{~h}^{-1}$ ) under the falling-rising rainfall, because the runoff generated during the first rainfall peak quickly flowed out of the slope. Thus, the cumulative infiltration of falling-rising rainfall was lower than the constant rainfall when projective slope length was shorter than $50 \mathrm{~m}$ (Figure 8), leading to larger total runoff, peak discharge (Figures 3a and 4a) and erosion depth (Figure 9) than those of the constant rainfall. As slope length increased, for the falling-rising rainfall, the runoff generated during the first half of the event lasted longer before flowed out so that more water infiltrated downstream the slope during the low rainfall intensity period. Meanwhile, the recession period of the falling-rising rainfall became much longer than that of the constant rainfall (e.g., Figure 4c,d), which dramatically increased the cumulative infiltration (Figure 8). Due to these reasons, when slope length was over $100 \mathrm{~m}$, the runoff coefficient of the constant rainfall became higher than that of the falling-rising rainfall (Figure 3c,d). Because of less infiltration downstream, less sediment deposited downstream the slope under the constant rainfall than the falling-rising rainfall (Figure 9), resulting in higher soil erosion amount when the slope length was over $100 \mathrm{~m}$ (Figure $5 \mathrm{c}, \mathrm{d}$ ). The results of the 
falling-rising rainfall indicated that, the runoff and soil erosion amount of such multi-peak rainfall may even lower than those of the uniform rainfall, especially when the slope length was long.

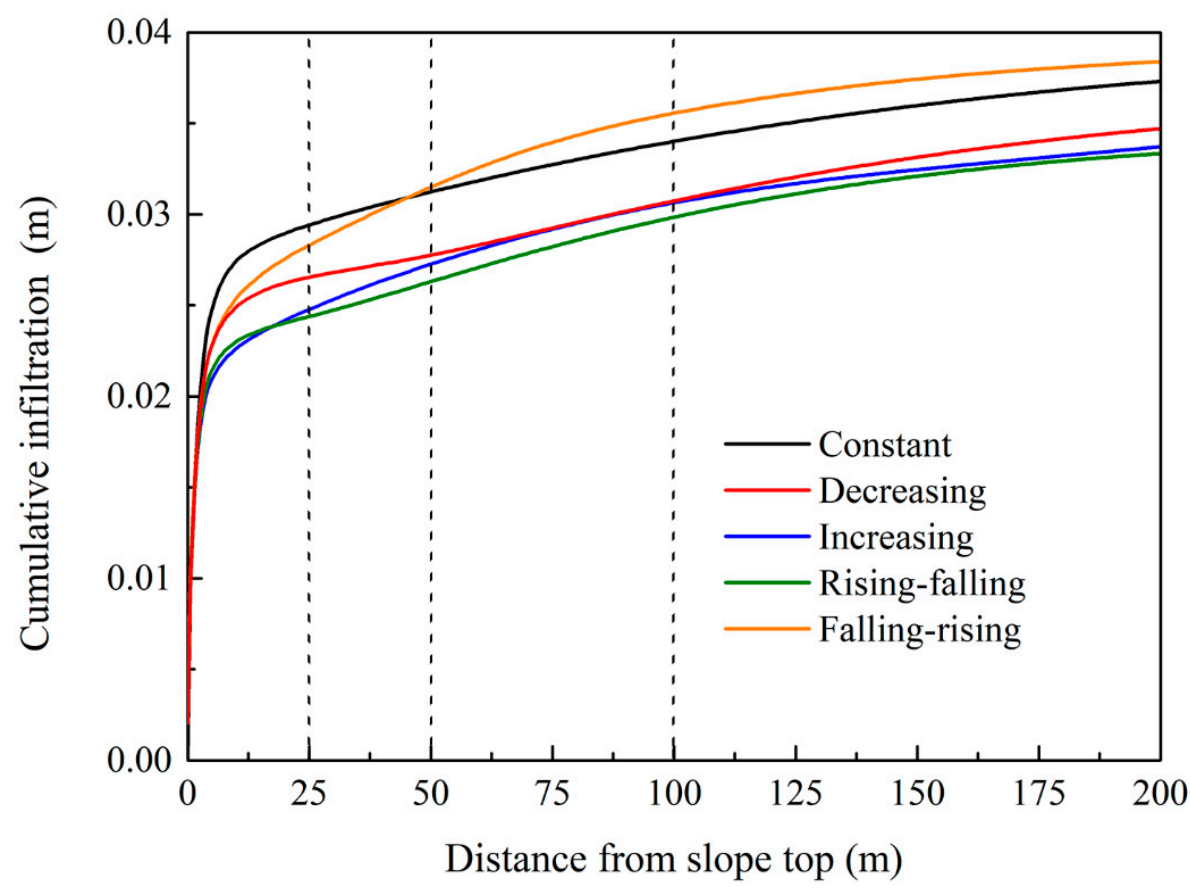

Figure 8. The cumulative infiltration distribution along the slope axis at the $15^{\circ}$ slope.

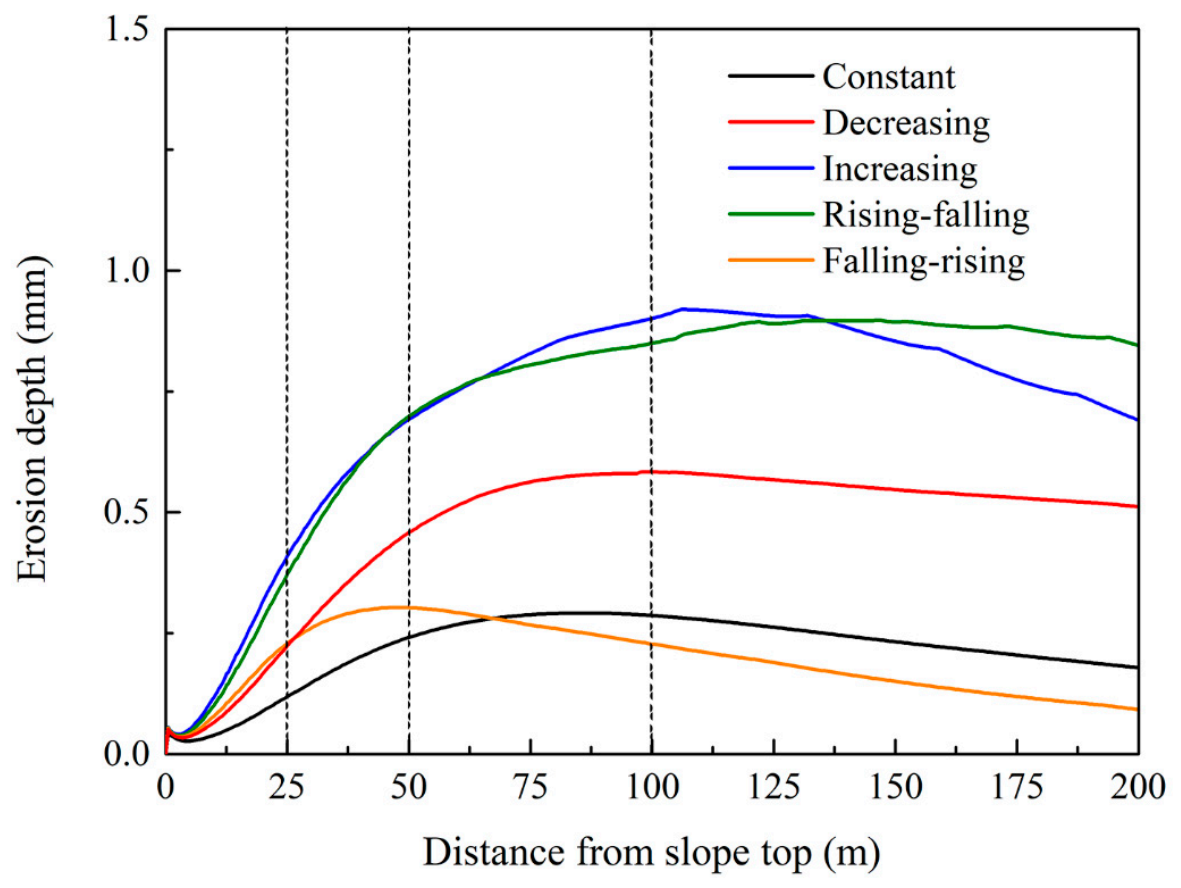

Figure 9. The erosion depth distribution along the slope axis at the $15^{\circ}$ slope.

The total runoff and soil erosion of decreasing rainfall were much lower than those of increasing rainfall and rising-falling rainfall. It was in agreement with the experimental research on small plots by Dunkerley [3], which found the runoff ratio of late peak rainfall was double that of early peak rainfall, and numerical simulation research by Zhai et al. [11], which reported that the delayed rainfall pattern yield higher flood volume and peak than the early peak pattern. The reason was that the soil infiltrability remained high in the early part of the event under decreasing rainfall [36]. 
Higher cumulative infiltration of decreasing rainfall compared with those of increasing rainfall and rising-falling rainfall was obvious, especially when the projective slope length was shorter than $50 \mathrm{~m}$ (e.g., Figure 8). Moreover, the smaller total runoff and peak discharge under decreasing rainfall (e.g., Figure $4 \mathrm{a}, \mathrm{c}$ ) led to shallower erosion depth (Figure 8), due to much lower stream power and sediment transport capacity.

The simulation results also indicated that the rising-falling rainfall had the highest runoff and soil erosion amount than other rainfall patterns when projective slope length was over $50 \mathrm{~m}$ (Tables 2 and 3), which was not consistent with previous studies. Dunkerley [3] indicated that the late peak rainfall had the highest peak runoff rate and runoff ratio. An et al. [8] reported that in their rainfall experiments the soil loss under increasing rainfall were the highest. The main reason was that, compared with rising-falling rainfall, the increasing rainfall had much longer recession period when slope was long (e.g., Figure $4 \mathrm{c}, \mathrm{d}$ ), leading to larger amount of infiltration and sediment deposition.

\subsection{The Impact of Slope Gradient on Total Runoff and Erosion under Five Rainfall Patterns}

From Figures 3 and 5 it can be seen that, for all the five different rainfall patterns, total runoff or total soil erosion showed a trend that it increased with increasing slope gradient and then gradually decreased after a critical slope. The critical slope of the total runoff was $15^{\circ}$, which was independent of rainfall pattern and projective slope length. Taking the rising-falling rainfall as an example, Figure 10 shows the cumulative infiltration distribution along the slope axis at $10^{\circ}-20^{\circ}$ slopes. For slopes lower than $15^{\circ}$ (e.g., $10^{\circ}$ ), overland flow velocity was slower than that on the $15^{\circ}$ slope, thus leading to more infiltration, especially when the projective slope length was over $30 \mathrm{~m}$ (Figure 10). For slope steeper than $15^{\circ}$ (e.g., $20^{\circ}$ ), because the slope length was longer than the $15^{\circ}$ slope, overland flow had to travelled longer path to reach the outlet and caused more infiltration. It can be seen in Figure 10 that cumulative infiltration difference between $15^{\circ}$ and $20^{\circ}$ slopes was mainly lay in area $10-50 \mathrm{~m}$ and $150-200 \mathrm{~m}$ from the slope top. Wu et al. [37] also found the critical slope for runoff rate was around $11^{\circ}$ regardless of rainfall duration and slope length through a modified Green-Ampt model. The critical slope of total runoff may be affected by the surface condition (e.g., vegetation coverage, surface roughness) and the soil property (e.g., permeability, soil surface sealing), which worth further investigation.

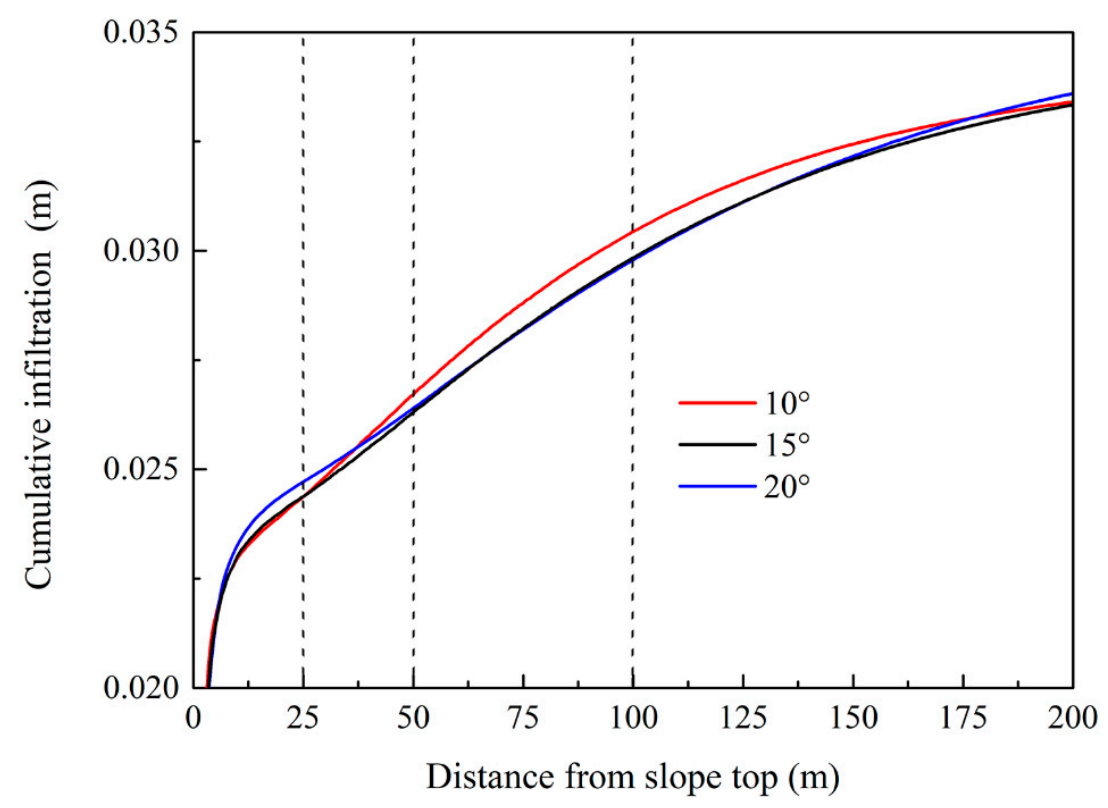

Figure 10. The cumulative infiltration distribution along the slope axis under rising-falling rainfall at $10^{\circ}-20^{\circ}$ slopes. 
The critical slope of soil erosion amount decreased from $35^{\circ}$ to $25^{\circ}$ when projective slope length increased under five different rainfall patterns (Figure 5), except for constant rainfall at $25 \mathrm{~m}$ slope length. Such simulation result was close to the range of critical slope of soil loss often observed in the field, which was $20^{\circ}-30^{\circ}$ (e.g., [21,38]). The smaller critical slope maybe because their rainfall experiments adopted slopes with equal length. Generally, the critical slope for the constant rainfall was $5^{\circ}$ larger than those of other rainfalls. Taking the rising-falling rainfall as an example, Figure 11 shows the erosion depth distribution along the slope axis at $25^{\circ}-35^{\circ}$ slopes. At $35^{\circ}$ slope, the erosion depth curve rose more quickly than other slopes as projective slope length increased to $25 \mathrm{~m}$, due to higher flow velocity and shear stress. Thus, the critical slope of soil erosion amount was $35^{\circ}$ for the slope shorter than $25 \mathrm{~m}$. As mentioned above, for slope steeper than $15^{\circ}$, the increase of slope gradient resulted in longer slope length and more infiltration. As the projective slope length increased, for each rainfall pattern, the reduction of runoff from $25^{\circ}$ slope to $35^{\circ}$ slope became larger (Figure 3) so that more sediment deposited on the slope. In consequence, the erosion depth curve at $25^{\circ}$ slope finally reached the highest peak and decreased much slower than the other slopes when the projective slope length over $50 \mathrm{~m}$ (Figure 11). The critical slope of soil erosion amount was $25^{\circ}$ for the slope longer than $100 \mathrm{~m}$.

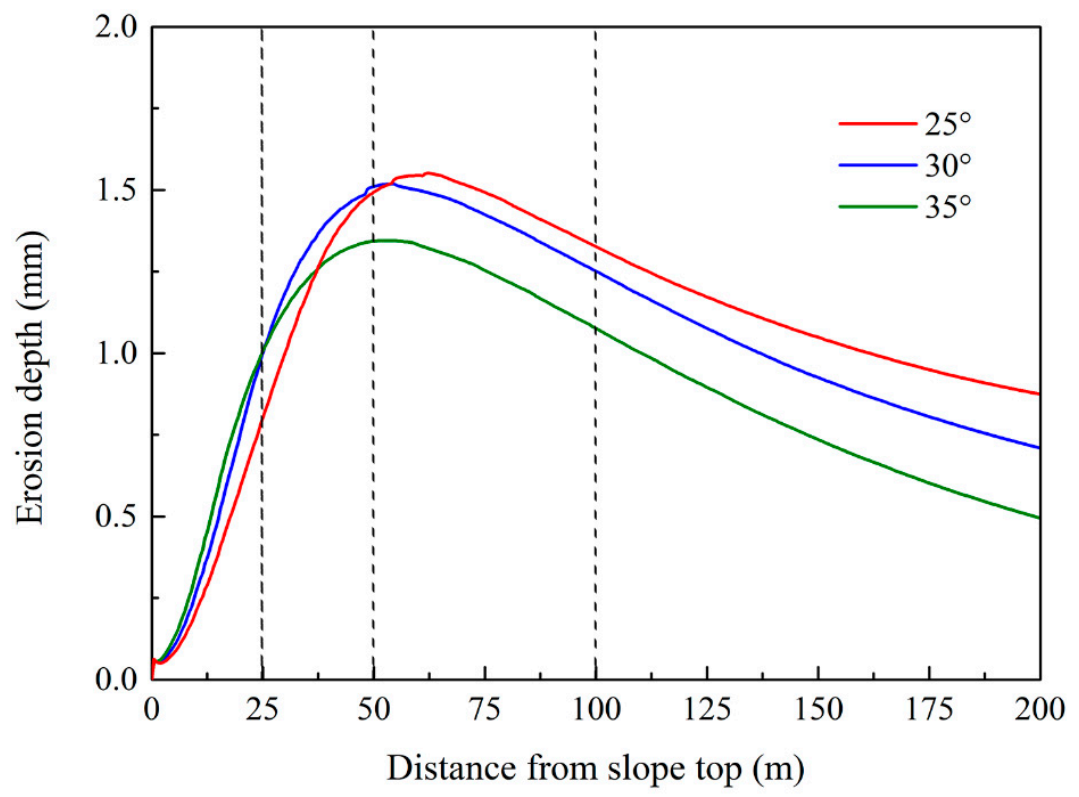

Figure 11. The erosion depth distribution along the slope axis under rising-falling rainfall at $25^{\circ}-35^{\circ}$ slopes.

\subsection{Effect of Rainfall Patterns on Runoff and Soil Erosion Peaks}

The time and value of the peak discharge as well as peak erosion rate were greatly influenced by the rainfall pattern. For the non-constant rainfall patterns, the increasing rainfall had the highest peak discharges and peak erosion rates, which was also mentioned in previous studies (e.g., [33]). Under increasing rainfall, as the rainfall intensity gradually increased and the surface gradually became saturated, the discharge rate and soil erosion rate kept increasing and reached the highest peak discharge and erosion rate (e.g., Figures 4 and 6) [39].

Because the infiltrability of the surface soil was high in the early part of the event, the decreasing and rising-falling rainfalls generally had lower peak discharges and peak erosion rates than the increasing rainfall (Figures 4 and 6). The peak discharge and erosion rate of increasing rainfall were reached just at the end of the peak rainfall intensity, while those of decreasing rainfall were several minutes later than the end of the peak rainfall intensity. High infiltrability of the surface soil in the early part of the event may be also the reason for the delay of the peak discharge and erosion rate, which dramatically slowed down the runoff generation process. Under rising-falling rainfall, the time 
of the peak discharge and erosion rate was also later than the end of the peak rainfall intensity, but the time was shorter than that under decreasing rainfall as its peak time was during the middle of the event.

For the falling-rising rainfall, as the two high rainfall intensity periods were separated by the low-rainfall-intensity period (Figure 2), the rainfall amount for peak discharge was much less than other non-constant rainfalls. Thus, the peak discharges and erosion rates were lower than those the increasing rainfall (Figures 4 and 6). As projective slope length increased, the effect of rainfall amount was more important so that the peak discharge and erosion rate under falling-rising rainfall was even lower than those of the decreasing rainfall on the $200 \mathrm{~m}$ slope.

\subsection{Benefits and Future Work}

This research work provided comprehensive theoretical studies on effects of rainfall patterns at slope scale. Even though it lacked field measurements as validation, the parameters of the slope that used in this study were well validated previously so the simulation results were rational and realistic for runoff and sediment research. The lumped and distributed simulation results showed how rainfall patterns affected runoff generation and soil erosion processes on the wide ranges of slope gradient $\left(5^{\circ}\right.$ to $\left.40^{\circ}\right)$ and length $(25-200 \mathrm{~m})$, which can improve the accuracy of hillslope runoff and soil erosion prediction and be helpful for catchment flood management.

Table 4 illustrates the comparison between this study and previous studies, aiming at identifying the differences and emphasizing the findings of this study. In the future, the effect of rainfall patterns on hydrological responses at catchment scale will be explored. This study indicated that slope length and steepness may have great influence on the impact of rainfall patterns, and different features of hillslope length and steepness in a natural catchment will be carefully considered. Besides, rainfall patterns with multi-peak (e.g., falling-rising rainfall) showed great variety in runoff and soil erosion amount at different slope length compared with other rainfall patterns so more research effort can be put into it.

Table 4. Comparison of the findings between the current and previous studies.

\begin{tabular}{|c|c|c|c|c|}
\hline Source & Experiment Setup & Scenario Arrangement & Finding & $\begin{array}{l}\text { Comparison with } \\
\text { This Study }\end{array}$ \\
\hline Parsons and Stone [10] & $\begin{array}{l}2.43 \text { m-long, } 0.9 \text { m-width, } \\
0.2 \text { m-depth flume, } \\
10^{\circ} \text { slope, three soil types. }\end{array}$ & $\begin{array}{c}\text { Intensity from } 46.4 \\
\text { to } 170.8 \mathrm{~mm} \mathrm{~h}^{-1} \\
93.9 \mathrm{~mm} \mathrm{~h}^{-1} \text { on average. }\end{array}$ & $\begin{array}{l}\text { A constant-intensity } \\
\text { storm are reduced by } \\
\text { about } 25 \% \text { compared to } \\
\text { varied-intensity storms. }\end{array}$ & \multirow{4}{*}{$\begin{array}{l}\text { 1. Conform part: Total } \\
\text { runoff and soil erosion } \\
\text { were lower than those } \\
\text { of increasing, } \\
\text { decreasing and } \\
\text { rising-falling rainfalls. } \\
\text { 2. Non conform part: } \\
\text { The rising-falling } \\
\text { rainfall generally had } \\
\text { the largest runoff and } \\
\text { soil erosion amount, } \\
\text { while the constant } \\
\text { rainfall did not have } \\
\text { the lowest ones when } \\
\text { the projective slope } \\
\text { length was over } 100 \mathrm{~m} \text {. }\end{array}$} \\
\hline An et al. [8] & $\begin{array}{c}8 \mathrm{~m} \text {-long, } 1.6 \mathrm{~m} \text {-width, } \\
0.2 \mathrm{~m} \text {-depth flume, } 5^{\circ} \text { and } \\
10^{\circ} \text { slope, pre wetted silt } \\
\text { loam soil. }\end{array}$ & $\begin{array}{c}\text { Intensity from } 50 \\
\text { to } 100 \mathrm{~mm} \mathrm{~h}^{-1} \\
75 \mathrm{~mm} \mathrm{~h}^{-1} \text { on average. }\end{array}$ & $\begin{array}{c}\text { Soil loss from } \\
\text { varying-intensity } \\
\text { rainfalls was } 1.13 \\
\text { to } 5.17 \text { times greater } \\
\text { than that from } \\
\text { even-intensity rainfall. } \\
\text { Soil loss under } \\
\text { increasing rainfall } \\
\text { were the highest. }\end{array}$ & \\
\hline Dunkerley [3] & $\begin{array}{c}0.5 \mathrm{~m} \times 0.5 \mathrm{~m} \text { plot, } \\
0.2^{\circ} \text { slope, loam soil. }\end{array}$ & $\begin{array}{c}\text { Intensity peaked at } \\
30 \mathrm{~mm} \mathrm{~h}^{-1}, 10 \mathrm{~mm} \mathrm{~h}^{-1} \\
\text { on average. }\end{array}$ & $\begin{array}{l}\text { Late peak events had } \\
\text { the highest peak runoff } \\
\text { rate and runoff ratio, } \\
\text { which were more than } \\
\text { double those of the } \\
\text { early peak events. } \\
\text { The constant rainfall } \\
\text { yielded the lowest total } \\
\text { runoff and runoff rate. }\end{array}$ & \\
\hline Wang et al. [35] & $\begin{array}{c}2 \mathrm{~m} \text {-long, } 1 \text { m-width, } \\
0.5 \mathrm{~m} \text {-depth flume, } \\
10^{\circ} \text { slope, pre wetted clay } \\
\text { loam soil. }\end{array}$ & $\begin{array}{c}\text { Intensity from } 50 \\
\text { to } 100 \mathrm{~mm} \mathrm{~h}^{-1} \\
75 \mathrm{~mm} \mathrm{~h}^{-1} \text { on average. }\end{array}$ & $\begin{array}{l}\text { The constant rainfall } \\
\text { produced the lowest } \\
\text { sediment yield at } \\
\text { around } 61.8 \% \text { of the } \\
\text { average soil loss for the } \\
\text { increasing rainfall, } \\
\text { which had the highest } \\
\text { soil loss. }\end{array}$ & \\
\hline
\end{tabular}


Table 4. Cont.

\begin{tabular}{ccccc}
\hline Source & Experiment Setup & Scenario Arrangement & Finding & $\begin{array}{c}\text { Comparison with } \\
\text { This Study }\end{array}$ \\
\hline Zhai et al. [11] & $\begin{array}{c}\text { Hydrological simulation } \\
\text { study at catchment } \\
\text { around } 100 \mathrm{~km}^{2} .\end{array}$ & $\begin{array}{c}\text { Intensity from } 7 \\
\text { to } 69 \mathrm{~mm} \mathrm{~h}^{-1} \\
\text { about } 20 \mathrm{~mm} \mathrm{~h}^{-1} \\
\text { on average }\end{array}$ & $\begin{array}{c}\text { The delayed rainfall } \\
\text { pattern yield higher } \\
\text { flood volume and peak } \\
\text { than the early } \\
\text { peak pattern. }\end{array}$ & Consensus \\
Wu et al. [37] & $\begin{array}{c}\text { Theoretical framework } \\
\text { work at } 22.1 \mathrm{~m} \text { long slopes } \\
\text { from } 0.5^{\circ} \text { to } 60^{\circ} .\end{array}$ & No description. & $\begin{array}{c}\text { Critical slope for runoff } \\
\text { rate was around } 11^{\circ} \\
\text { regardless of rainfall } \\
\text { duration and } \\
\text { slope length }\end{array}$ & $\begin{array}{c}\text { The critical slope of the } \\
\text { runoff was close, and } \\
\text { was also independent } \\
\text { of slope length. }\end{array}$ \\
\hline Cheng et al. [38] & $\begin{array}{c}2 \mathrm{~m} \times 5 \mathrm{~m} \text { plot, } 5^{\circ} \text { to } 25^{\circ} \\
\text { slope, sandy loam soil. }\end{array}$ & $\begin{array}{c}72 \mathrm{~mm} \mathrm{~h}^{-1} \text { rainfall } \\
\text { for } 30 \mathrm{~min} .\end{array}$ & $\begin{array}{c}\text { Soil loss increased with } \\
\text { increasing slope angle } \\
\text { till the critical slope } \\
\text { angle of } 20^{\circ}-30^{\circ} .\end{array}$ & $\begin{array}{c}\text { The range of critical } \\
\text { slope of the soil } \\
\text { erosion was close. }\end{array}$ \\
\hline
\end{tabular}

Additionally, in the modelling study a stable slope surface was assumed, which meant that evolution of rill was not considered on the surface. On steep and long hillslopes, rill may generate under heavy rainfall (e.g., [40]). As the surface flow and related soil erosion characteristics in rills are different from those in an interrill area [41], it may influence the runoff generation and erosion dynamics at various scales. Although addressing the influence of rill was beyond the scope of this study, it is worth further investigations.

\section{Conclusions}

In this study, the effect of rainfall pattern on runoff generation and soil erosion processes on slopes were analysed through numerical modelling. The modelling work provides infiltration, runoff and soil erosion differences among five rainfall patterns on wide ranges of slope gradient $\left(5^{\circ}\right.$ to $\left.40^{\circ}\right)$ and slope length $(25-200 \mathrm{~m})$. The simulation result indicated that the rising-falling rainfall generally had the largest total runoff and soil erosion amount. The constant rainfall did not have the lowest total runoff and soil erosion amount when the projective slope length was over $100 \mathrm{~m}$, which was higher than the falling-rising rainfall. The critical slope of the total runoff was $15^{\circ}$, which was independent of rainfall pattern and slope length. However, the critical slope of the soil erosion amount varied, which decreased with increasing projective slope length from $35^{\circ}$ to $25^{\circ}$. And the critical slope for the soil erosion of the constant rainfall was generally $5^{\circ}$ larger than that of other rainfalls. The increasing rainfall had the highest peak discharge and erosion rate just at the end of the peak rainfall intensity, while those of the decreasing and rising-falling rainfalls were lower and were several minutes later than the end of peak rainfall intensity.

These findings are helpful to improve the knowledge of the characteristics in runoff generation and soil erosion processes under various rainfall patterns at slopes, and they may be also beneficial for further understanding of hillslope morphology and ecology. Further work will be required for adequate meteorological and hydrological data to gain a more comprehensive understanding of rainfall pattern effects on hydrological processes at larger scale.

Author Contributions: Conceptualization, Q.R. and F.W.; Investigation, F.W. and J.G.; Writing-Original Draft Preparation, F.W. and J.G.; Writing-Review \& Editing, Q.R. and J.G.

Funding: This research was funded by National Key Research and Development Program of China (2016YFC0402404) and National Natural Scientific Foundation of China (51679209).

Conflicts of Interest: The authors declare no conflict of interest. 


\section{References}

1. Dunkerley, D. Rain event properties in nature and in rainfall simulation experiments: A comparative review with recommendations for increasingly systematic study and reporting. Hydrol. Process. 2008, 22, 4415-4435. [CrossRef]

2. Farrick, K.K.; Branfireun, B.A. Soil water storage, rainfall and runoff relationships in a tropical dry forest catchment. Water Resour. Res. 2014, 50, 9236-9250. [CrossRef]

3. Dunkerley, D. Effects of rainfall intensity fluctuations on infiltration and runoff: Rainfall simulation on dryland soils, fowlers gap, australia. Hydrol. Process. 2012, 26, 2211-2224. [CrossRef]

4. Singh, V.P. Effect of spatial and temporal variability in rainfall and watershed characteristics on stream flow hydrograph. Hydrol. Process. 1997, 11, 1649-1669. [CrossRef]

5. Cerdan, O.; Bissonnais, Y.L.; Couturier, A.; Bourennane, H.; Souchère, V. Rill erosion on cultivated hillslopes during two extreme rainfall events in normandy, france. Soil Tillage Res. 2002, 67, 99-108. [CrossRef]

6. Dolšak, D.; Bezak, N.; Šraj, M. Temporal characteristics of rainfall events under three climate types in slovenia. J. Hydrol. 2016, 541, 1395-1405. [CrossRef]

7. Huff, F.A. Time distribution of rainfall in heavy storms. Water Resour. Res. 1967, 3, 1007-1019. [CrossRef]

8. An, J.; Zheng, F.L.; Han, Y. Effects of rainstorm patterns on runoff and sediment yield processes. Soil Sci. 2014, 179, 293-303. [CrossRef]

9. Dunkerley, D. An approach to analysing plot scale infiltration and runoff responses to rainfall of fluctuating intensity. Hydrol. Process. 2017, 31, 191-206. [CrossRef]

10. Parsons, A.J.; Stone, P.M. Effects of intra-storm variations in rainfall intensity on interrill runoff and erosion. Catena 2006, 67, 68-78. [CrossRef]

11. Zhai, X.Y.; Guo, L.; Liu, R.H.; Zhang, Y.Y. Rainfall threshold determination for flash flood warning in mountainous catchments with consideration of antecedent soil moisture and rainfall pattern. Nat. Hazards 2018, 94, 605-625. [CrossRef]

12. Chen, L.; Sela, S.; Svoray, T.; Assouline, S. Scale dependence of hortonian rainfall-runoff processes in a semiarid environment. Water Resour. Res. 2016, 52, 5149-5166. [CrossRef]

13. Parsons, A.J.; Brazier, R.E.; Wainwright, J.; Powell, D.M. Scale relationships in hillslope runoff and erosion. Earth Surf. Process. Landf. 2006, 31, 1384-1393. [CrossRef]

14. Langhans, C.; Govers, G.; Diels, J.; Stone, J.J.; Nearing, M.A. Modeling scale-dependent runoff generation in a small semi-arid watershed accounting for rainfall intensity and water depth. Adv. Water Resour. 2014, 69, 65-78. [CrossRef]

15. Guntner, A.; Bronstert, A. Representation of landscape variability and lateral redistribution processes for large-scale hydrological modelling in semi-arid areas. J. Hydrol. 2004, 297, 136-161. [CrossRef]

16. Stomph, T.J.; Ridder, N.D.; Steenhuis, T.S.; Giesen, N.C.V.D. Scale effects of hortonian overland flow and rainfall-runoff dynamics: Laboratory validation of a process-based model. Earth Surf. Process. Landf. 2002, 27, 847-855. [CrossRef]

17. Assouline, S.; Ben-Hur, M. Effects of rainfall intensity and slope gradient on the dynamics of interrill erosion during soil surface sealing. Catena 2006, 66, 211-220. [CrossRef]

18. Essig, E.T.; Corradini, C.; Morbidelli, R.; Govindaraju, R.S. Infiltration and deep flow over sloping surfaces: Comparison of numerical and experimental results. J. Hydrol. 2009, 374, 30-42. [CrossRef]

19. Defersha, M.B.; Quraishi, S.; Melesse, A. The effect of slope steepness and antecedent moisture content on interrill erosion, runoff and sediment size distribution in the highlands of ethiopia. Hydrol. Earth Syst. Sci. 2011, 15, 2367-2375. [CrossRef]

20. Shi, Z.H.; Fang, N.F.; Wu, F.Z.; Wang, L.; Yue, B.J.; Wu, G.L. Soil erosion processes and sediment sorting associated with transport mechanisms on steep slopes. J. Hydrol. 2012, 454, 123-130. [CrossRef]

21. Cheng, Q.; Ma, W.; Cai, Q. The relative importance of soil crust and slope angle in runoff and soil loss: A case study in the hilly areas of the loess plateau, north china. GeoJournal 2008, 71, 117-125. [CrossRef]

22. Chaplot, V.A.M.; Le Bissonnais, Y. Runoff features for interrill erosion at different rainfall intensities, slope lengths, and gradients in an agricultural loessial hillslope. Soil Sci. Soc. Am. J. 2003, 67, 844-851. [CrossRef] 
23. Ebel, B.A.; Loague, K.; Montgomery, D.R.; Dietrich, W.E. Physics-based continuous simulation of long-term near-surface hydrologic response for the coos bay experimental catchment. Water Resour. Res. 2008, 44, 137-149. [CrossRef]

24. Ran, Q.; Keith, L.; Verkwaak, J.E. Hydrologic-response-driven sediment transport at a regional scale, process-based simulation. Hydrol. Process. 2012, 26, 159-167. [CrossRef]

25. Ebel, B.A.; Loague, K.; Borja, R.I. The impacts of hysteresis on variably saturated hydrologic response and slope failure. Environ. Earth Sci. 2010, 61, 1215-1225. [CrossRef]

26. VanderKwaak, J.E.; Loague, K. Hydrologic-response simulations for the r-5 catchment with a comprehensive physics-based model. Water Resour. Res. 2001, 37, 999-1013. [CrossRef]

27. VanderKwaak, J.E. Numerical Simulation of Flow and Chemical Transport in Integrated Surface-Subsurface Hydrologic Systems. Ph.D. Thesis, University of Waterloo, Waterloo, ON, Canada, 1999.

28. Ran, Q.; Heppner, C.S.; Vanderkwaak, J.E.; Loague, K. Further testing of the integrated hydrology model (inhm): Multiple-species sediment transport. Hydrol. Process. 2007, 21, 1522-1531. [CrossRef]

29. Ran, Q.; Hong, Y.; Li, W.; Gao, J. A modelling study of rainfall-induced shallow landslide mechanisms under different rainfall characteristics. J. Hydrol. 2018, 563, 790-801. [CrossRef]

30. Heppner, C.S.; Ran, Q.; Vanderkwaak, J.E.; Loague, K. Adding sediment transport to the integrated hydrology model (inhm): Development and testing. Adv. Water Resour. 2006, 29, 930-943. [CrossRef]

31. Johansen, M.P.; Hakonson, T.E.; Breshears, D.D. Post-fire runoff and erosion from rainfall simulation: Contrasting forests with shrublands and grasslands. Hydrol. Process. 2001, 15, 2953-2965. [CrossRef]

32. Van Genuchten, M.T. A closed-form equation for predicting the hydraulic conductivity of unsaturated soils. Soil Sci. Soc. Am. J. 1980, 44, 892-898. [CrossRef]

33. Gao, J.; Kirkby, M.; Holden, J. The effect of interactions between rainfall patterns and land-cover change on flood peaks in upland peatlands. J. Hydrol. 2018, 567, 546-559. [CrossRef]

34. Flanagan, D.C.; Foster, G.R.; Moldenhauer, W.C. Storm pattern effect on infiltration, runoff, and erosion. Trans. ASAE 1988, 31, 546-559. [CrossRef]

35. Wang, B.; Steiner, J.; Zheng, F.; Gowda, P. Impact of rainfall pattern on interrill erosion process. Earth Surf. Process. Landf. 2017, 42, 1833-1846. [CrossRef]

36. Xue, J.; Gavin, K. Effect of rainfall intensity on infiltration into partly saturated slopes. Geotech. Geol. Eng. 2008, 26, 199-209. [CrossRef]

37. Wu, S.; Yu, M.; Chen, L. Nonmonotonic and spatial-temporal dynamic slope effects on soil erosion during rainfall-runoff processes. Water Resour. Res. 2017, 53, 1369-1389. [CrossRef]

38. Liu, Q.Q.; Xiang, H.; Singh, V.P. A simulation model for unified interrill erosion and rill erosion on hillslopes. Hydrol. Process. 2006, 20, 469-486. [CrossRef]

39. Dunkerley, D. Stemflow production and intrastorm rainfall intensity variation: An experimental analysis using laboratory rainfall simulation. Earth Surf. Process. Landf. 2014, 39, 1741-1752. [CrossRef]

40. Fang, H.; Sun, L.; Tang, Z. Effects of rainfall and slope on runoff, soil erosion and rill development: An experimental study using two loess soils. Hydrol. Process. 2015, 29, 2649-2658. [CrossRef]

41. Wirtz, S.; Seeger, M.; Ries, J.B. Field experiments for understanding and quantification of rill erosion processes. Catena 2012, 91, 21-34. [CrossRef]

(C) 2019 by the authors. Licensee MDPI, Basel, Switzerland. This article is an open access article distributed under the terms and conditions of the Creative Commons Attribution (CC BY) license (http://creativecommons.org/licenses/by/4.0/). 